WSRC-TR-2001-00126

\title{
MELT RATE IMPROVEMENT FOR MB3: Feed Preparation
}

\author{
M. E. Stone \\ D. P. Lambert
}

Westinghouse Savannah River Company

Savannah River Site

Aiken, SC 29808

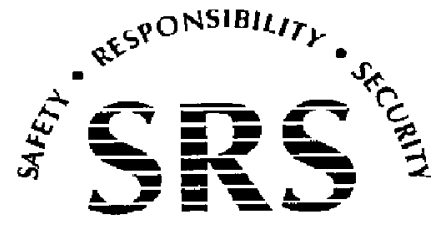

PREPARED FOR THE U.S. DEPARTMENT OF ENERGY UNDER CONTRACT NO. DE-AC09-96SR18500 
This document was prepared in conjunction with work accomplished under Contract No.

DE-AC09-96SR18500 with the U.S. Department of Energy.

\section{DISCLAIMER}

This report was prepared as an account of work sponsored by an agency of the United States Government. Neither the United States Government nor any agency thereof, nor any of their employees, makes any warranty, express or implied, or assumes any legal liability or responsibility for the accuracy, completeness, or usefulness of any information, apparatus, product or process disclosed, or represents that its use would not infringe privately owned rights. Reference herein to any specific commercial product, process or service by trade name, trademark, manufacturer, or otherwise does not necessarily constitute or imply its endorsement, recommendation, or favoring by the United States Government or any agency

thereof. The views and opinions of authors expressed herein do not necessarily state or reflect those of the United States Government or any agency thereof.

This report has been reproduced directly from the best available copy.

Available for sale to the public, in paper, from: U.S. Department of Commerce, National Technical Information Service, 5285 Port Royal Road, Springfield, VA 22161, phone: (800)

553-6847, fax: (703) 605-6900, email: orders@ntis.fedworld.gov online ordering: http://www.ntis.gov/ordering.htm

Available electronically at http://www.doe.gov/bridge

Available for a processing fee to U.S. Department of Energy and its contractors, in paper, from: U.S. Department of Energy, Office of Scientific and Technical Information, P.O. Box 62, Oak Ridge, TN 37831-0062, phone: (865 ) 576-8401, fax: (865) 576-5728, email: reports@ adonis.osti.gov 
Keywords: DWPF

Vitrification,

Melt Rate

Feed

Preparation

Retention: Permanent

\title{
MELT RATE IMPROVEMENT FOR MB3: \\ Feed Preparation
}

\author{
M. E. Stone \\ D. P. Lambert
}

Publication Date: April 1, 2001

Westinghouse Savannah River Company

Savannah River Site

Aiken, SC 29808

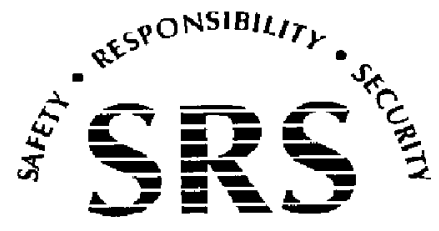

PREPARED FOR THE U.S. DEPARTMENT OF ENERGY UNDER CONTRACT NO. DE-AC09-96SR18500 


\section{APPROVALS}

M. E. Stone, Author

Date

Immobilization Technology Section

D. P. Lambert, Author

Date

Immobilization Technology Section

D. C. Witt, Technical Reviewer

Date

Immobilization Technology Section

S. L. Marra, Manager

Date

Glass Form \& Process Development Group - DWPF

E. W. Holtzscheiter, Manager

Date

Immobilization Technology Section 


\section{TABLE OF CONTENTS}

1.0 INTRODUCTION .....................................................................................................1

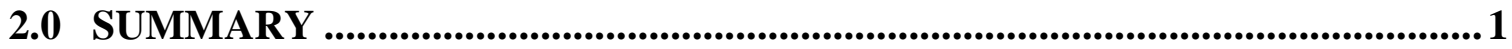

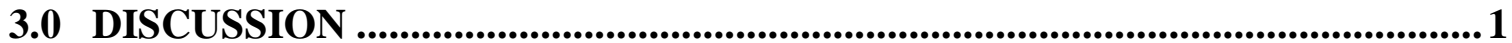

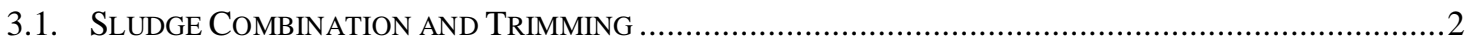



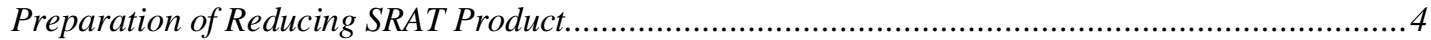

Preparation of Overwashed SRAT Product .................................................................... 5

Preparation of Underwashed SRAT Product ...................................................................... 5

3.3. MELTER FEEd PreParation AND DRYING..................................................................5

APPENDIX A: MACROBATCH 3 SRAT PRODUCT PREPARATION.................. 10

APPENDIX B: MACROBATCH 3 SLUDGE PREPARATION.................................. 10

4.0 REFERENCES ........................................................................................................... 11 
WSRC-TR-2001-00126

Page 1 of 11

\subsection{INTRODUCTION}

The Defense Waste Processing Facility (DWPF) would like to increase its canister production rate. A study ${ }^{1}$ was completed in FY00 to look for processing and frit changes that would improve the melting rate of the glass in the DWPF melter specifically for Macrobatch 2 (Sludge batch 1B). This study concluded a change from Frit 200 to Frit 165 is expected to increase the melt rate in DWPF without decreasing waste loading ${ }^{1}$.

DWPF requested that SRTC complete a new melt rate study ${ }^{2}$ for Macrobatch 3 (Sludge batch 2), the next sludge batch that will be processed by DWPF. This task is more extensive than the Macrobatch 2 study ${ }^{1}$. The Macrobatch 2 study looked at existing frits only while the Macrobatch 3 study was directed to develop new frits and evaluate processing changes to improve melt rate ${ }^{3}$.

The proposed DWPF flowsheet for nominal Macrobatch 3 sludge $^{4}$ has been tested extensively using simulated sludge. The chemical processing recommended is similar to Macrobatch 2 in that it utilizes a combination of nitric acid and formic acid during the melter feed preparation to produce a glass with a predicted $\mathrm{Fe}^{+2} / \Sigma \mathrm{Fe}$ ratio of approximately 0.20 . Frit 200 was utilized as the glass former. The Macrobatch 3 melt rate study focuses on two changes to improve melt rate: (1) changes in frit composition, and (2) changes to the feed preparation process to alter the redox of the melter feed. These two factors were investigated for Macrobatch 3 (Sludge batch 2) utilizing crucible studies and a specially designed "melt rate" furnace. Other potential factors that could increase melt rate that are being investigated by separate programs include: mechanical mixing via stirring or the use of bubblers, changing the power skewing to redistribute the power input to the melter, and elimination of heat loss (e.g. air inleakage).

\subsection{SUMMARY}

This report describes the non-radioactive preparation of Macrobatch 3 simulated sludge and Macrobatch 3 Sludge Receipt and Adjustment Tank (SRAT) products necessary for the FY01 melt rate testing. The SRAT products were combined with various frits, dried and size-reduced to produce the dried melter feeds that were used in the crucible and melt rate furnace testing. The results of the crucible and melt rate furnace testing will be summarized in separate reports.

One three-liter and four fifteen-liter batches of nominal Macrobatch 3 SRAT product were produced to support this testing. In addition, three-liter batches representing three processing options were prepared; (1) reducing SRAT product, (2) underwashed SRAT product, and (3) overwashed SRAT product. The underwashed SRAT product was of particular importance to DWPF because tank space and evaporator problems make it more likely that the next sludge batch will be underwashed.

\subsection{DISCUSSION}

All the testing was completed with melter feed prepared from Macrobatch 3 sludge simulant. The feed preparation process converted the Tank 8 and Tank 40 sludge simulant into feed for the melt 
WSRC-TR-2001-00126

Page 2 of 11

rate furnace and crucible testing. The feed preparation process was composed of three steps; 1 ) Combining the Tank 8 and Tank 40 sludge and adding trim chemicals to produce Tank 8/40 blended sludge simulant (Macrobatch 3 sludge), 2) Processing the sludge simulant through a Sludge Receipt and Adjustment Tank (SRAT) process, and 3) Combining the SRAT product with frit and removing water by drying in an oven. Note that no DWPF Slurry Mix Evaporator (SME) cycles were performed to prepare the melter feeds.

\subsection{Sludge Combination and Trimming}

The Macrobatch 3 sludge composition for nominally washed and underwashed sludge was predicted by Hank Elder ${ }^{5}$. This recipe was the basis for the sludge preparation. Macrobatch 3 is approximately 50\% Tank 40 sludge and 50\% Tank 8 sludge by weight. The two sludge simulants were prepared at the Fred Facility at the University of South Carolina ${ }^{6}$.

Three significant changes were made in preparing the SRAT products. First, no uranium was added to the sludge since there is no nonradioactive form of uranium that can be added and there is no known nonradioactive element that is a suitable replacement in the chemical processing and in the melter operations. Macrobatch 3 is high in uranium ( $8.6 \mathrm{wt} \% \mathrm{U}$ in calcined sludge solids) so this is a significant omission. Additional frit was added as a replacement for the uranium, therefore, the sludge content in glass was unchanged. Second, no mercury was added to the sludge since the melt rate furnace is not designed to handle the mercury vapors and the mercury is not part of the glass matrix (mercury is removed in DWPF chemical processing and any residual mercury in the melter feed is volatile and removed in the melter offgas). The mercury in MB3 is low ( $0.3 \mathrm{wt} \% \mathrm{Hg}$ in sludge solids). Third, no insoluble sodium was added in the sludge preparation process. To produce a SRAT product with the correct sodium concentration, the additional sodium was added to the sludge by the addition of sodium nitrate and sodium formate.

The Macrobatch 3 (Tank 8/40) sludge simulant was prepared by combining equal amounts (by weight) of Tank 8 and Tank 40 sludge simulant. The combined sludge was low in manganese and nickel so manganese (IV) oxide (85\%), nickel chloride hexahydrate, and noble metals were then added to trim the sludge to the required compositions. Sodium formate and sodium nitrate were added to the sludge to adjust the sodium concentration to desired levels. The ratio of sodium formate and sodium nitrate was calculated to maintain a targeted redox of $0.2 \mathrm{Fe}^{+2} / \Sigma \mathrm{Fe}$.

\subsection{SRAT Process}

A series of SRAT cycles were completed with simulated sludge to produce the SRAT products necessary for the planned crucible and melt rate tests. The SRAT cycles were fairly representative of the recommended processing for Macrobatch $3^{4}$. The SRAT cycles were completed over two days to give the same twelve hours of boiling as is the practice in a DWPF SRAT cycle and eliminate the need for overtime in the making of the SRAT product. This processing deviation had no impact on the chemical content of the SRAT product and did not impact the objective of this testing. The runs were completed using the SRAT cycle procedure ${ }^{7}$ and a run plan specific for each SRAT cycle. The data from the runs were recorded in a lab notebook ${ }^{8}$.

The baseline SRAT process was conducted in 3-liter batches and/or 15-liter batches. A schematic of the 15-liter batch setup is included in Figures 1, 2 and 3. The baseline SRAT cycle consisted 
of adding nitric acid and formic acid to acidify the sludge, concentrating the batch to the original volume, and then refluxing the batch for 8 hours. After the reflux, the SRAT product was concentrated to reduce the time required to dry the material after combining with frit. The nitric acid / formic acid ratio was adjusted to target a glass redox of $0.2 \mathrm{Fe}^{+2} / \Sigma \mathrm{Fe}$. A sample of each batch of SRAT product was analyzed to determine the calcine factor (amount of solids remaining after the sample is heated to $900^{\circ} \mathrm{C}$ ). The calcine factor was used to determine the amount of frit to add to produce melter feed.

Four different types of SRAT product were made: baseline (or nominal), reducing (formic acid only), underwashed, and overwashed. The reducing SRAT product was produced with formic acid only (no nitric acid) during the SRAT cycle. The underwashed SRAT product was produced by adding the soluble sodium salts removed during sludge washing to the simulated sludge to represent one less wash during sludge pretreatment. The overwashed sludge had an additional wash performed on the simulated sludge to reduce the sodium content by half. The amount of nitric acid and formic acid added was calculated to target a redox of $0.2 \mathrm{Fe}^{+2} / \Sigma \mathrm{Fe}$ for the nominal, underwashed and overwashed SRAT product. The composition of the nominal SRAT product is shown in Table 1. The run plan for this nominal SRAT product preparation is included in Appendix A-1. 
WSRC-TR-2001-00126

Page 4 of 11

Table 1. Composition of Baseline Macrobatch 3 SRAT Product (nominal)

\begin{tabular}{|l|c|c|}
\hline Solids & Analysis & Units \\
\hline Total solids & 18.85 & $\mathrm{Wt} \%$ \\
Soluble solids & 6.305 & $\mathrm{Wt} \%$ \\
Insoluble solids & 12.55 & $\mathrm{Wt} \%$ \\
Calcine solids & 14.45 & $\mathrm{Wt} \%$ \\
\hline
\end{tabular}

\begin{tabular}{|l|c|c|}
\hline Elements & $\begin{array}{c}\text { Wt\% Elemental } \\
\text { (Calcined Basis) }\end{array}$ & $\begin{array}{c}\text { Wt \% Oxide } \\
\text { (Calcined Basis) }\end{array}$ \\
\hline $\mathbf{A l}$ & 9.870 & 18.649 \\
$\mathbf{B}$ & 0.000 & 0.000 \\
$\mathbf{B a}$ & 0.267 & 0.298 \\
$\mathbf{C a}$ & 3.210 & 4.491 \\
$\mathbf{C r}$ & 0.253 & 0.370 \\
$\mathbf{C u}$ & 0.161 & 0.202 \\
$\mathbf{F e}$ & 36.000 & 51.469 \\
$\mathbf{K}$ & 0.128 & 0.154 \\
$\mathbf{L i}$ & 0.000 & 0.000 \\
$\mathbf{M g}$ & 0.147 & 0.243 \\
$\mathbf{M n}$ & 2.635 & 3.402 \\
$\mathbf{N a}$ & 10.450 & 14.087 \\
$\mathbf{N i}$ & 1.030 & 1.311 \\
$\mathbf{P}$ & 0.048 & 0.000 \\
$\mathbf{P b}$ & 0.231 & 0.249 \\
$\mathbf{S i}$ & 1.395 & 2.984 \\
$\mathbf{S r}$ & 0.116 & 0.137 \\
$\mathbf{T i}$ & 0.005 & 0.008 \\
$\mathbf{Z n}$ & 0.315 & 0.391 \\
$\mathbf{Z r}$ & 0.619 & 0.836 \\
$\mathbf{S u m}$ of Oxides & & 99.281 \\
\hline
\end{tabular}

A total of one 3-liter and four 15-liter batches were completed to produce approximately 60 liters of nominal Macrobatch 3 SRAT product. In addition, one 3-liter SRAT cycle was completed for each of the three processing options; formic acid only, underwashed sludge and overwashed sludge. This was enough material for the crucible studies and one melt rate furnace run for each of the processing options. The preparation of each of these processing changes is described below.

\section{Preparation of Reducing SRAT Product}

Adding only formic acid (no nitric acid) during the SRAT cycle produced the reducing SRAT product. The same nominal Macrobatch 3 sludge was used as with the nominal SRAT product. The reducing SRAT product contained the same moles of formic acid as were added as either

\footnotetext{
\# Based on analysis of sludge from experiments performed by David Koopman.
} 
WSRC-TR-2001-00126

Page 5 of 11

formic acid or nitric acid in the nominal SRAT product. The hydrogen generation rate was not measured during this SRAT product preparation. The run plan for producing reducing SRAT product is included in Appendix A-2.

\section{Preparation of Overwashed SRAT Product}

The overwashed sludge was prepared from $2800 \mathrm{~g}$ of nominal Macrobatch 3 sludge by (1) decanting $500 \mathrm{ml}$ of supernate, (2) adding $1075 \mathrm{~g}$ of water, (3) decanting $1075 \mathrm{ml}$ of supernate, and adding $500 \mathrm{~g}$ of DI water to the sludge. This is approximately equivalent to two additional washes of the sludge. The run plan for the overwashed sludge preparation is included in Appendix B-1. The sludge was analyzed as necessary to calculate the nitric and formic acid additions necessary for the SRAT cycle. The calculations and run plan for producing the overwashed sludge is included in Appendix A-3. The hydrogen generation rate was not measured during this SRAT product preparation.

\section{Preparation of Underwashed SRAT Product}

The underwashed sludge was prepared from $2800 \mathrm{~g}$ of nominal Macrobatch 3 sludge by adding additional sodium nitrate, sodium nitrite and sodium hydroxide to the sludge. This is approximately equivalent to one less wash cycle in preparing the sludge. The advantage of less washing is that the sludge preparation will be quicker and less spent wash water will be generated. Less spent wash water would be a significant advantage to the high level waste process because of the recent evaporator problems ${ }^{9}$. The run plan for the underwashed sludge preparation is included in Appendix B-2. The sludge was analyzed as necessary to calculate the nitric and formic acid additions necessary for the SRAT cycle. The calculations and run plan for producing the underwashed sludge are included in Appendix A-4. The hydrogen generation rate was not measured during this SRAT product preparation.

\subsection{Melter Feed Preparation and Drying}

For each crucible or melt rate furnace test, the required amount of SRAT product slurry was combined with the required amount of frit based on a waste loading of $23.2 \%$. This is equivalent to $26 \mathrm{wt} \%$ sludge oxide loading in glass $\left(26 \mathrm{wt} \%\right.$ sludge oxide loading contains $2.8 \mathrm{wt} \% \mathrm{U}_{3} \mathrm{O}_{8}$ in glass $-26-2.8 \mathrm{wt} \%=23.2 \mathrm{wt} \%$ uranium free sludge oxide loading in glass). This gives the correct solids concentration of iron, sodium and the other sludge elements in the glass. Of particular concern was the sodium concentration since many of the frits were developed to maximize the alkali content in an attempt to improve melt rate. If more sludge was added to replace the uranium, the concentration of sodium would have been higher in the glass than planned. This could lead to the development of frits that were lower in sodium than desired because of the high sodium content in the sludge. Since uranium was not added in these nonradioactive experiments, frit was added on a weight basis to replace the uranium. Thus a 25 $\mathrm{wt} \%$ sludge mixture with uranium would lead to a $23.2 \mathrm{wt} \%$ sludge mixture without the added uranium oxide.

The frit was added to the SRAT product as a dry powder (DWPF frit size range $<80$ mesh, $177 \mu \mathrm{m},>200 \mathrm{mesh}, 74 \mu \mathrm{m})$. No Slurry Mix Evaporator (SME) cycles were performed since the 
WSRC-TR-2001-00126

Page 6 of 11

frit was added as a dry powder. After batching, the melter feed was dried to the desired batch weight in an oven, then placed in a desiccator until ready to be vitrified.

During the first ten melt rate furnace tests, the melter feed slurry was dried under vacuum at $70^{\circ} \mathrm{C}$ to reduce the amount of formic acid lost during the drying process. The melter feed was dried to a final batch weight of 794 grams. At this batch weight, the feed for some runs had the consistency of peanut butter while other runs had the consistency of wet clay. The batch height varied from 2.5 " to 3.5 " during the ten runs.

As a result of the difference in batch height and problems with reproducibility of the initial runs, the feed was dried in an atmospheric convection oven at $105^{\circ} \mathrm{C}$ for the next six runs to a batch weight of $575 \mathrm{~g}$. The feed was then ground with a mortar and pestle and passed through a \#10 mesh screen $(<2 \mathrm{~mm})$. The resulting feed had a uniform appearance and batch height prior to firing. The batch weight for all remaining runs was $545 \pm 5$ grams.

The amount of dried SRAT product and frit to be combined for each of the crucible runs was calculated to produce $45 \mathrm{~g}$ of glass. The amount of dried SRAT product and frit to be combined for each of the melt rate furnace runs was calculated to produce $500 \mathrm{~g}$ of glass. The results are summarized in Table 2 for the nominal batches and in Table 3 for the alternative processing.

\section{Table 2 -- Melt Rate Furnace SRAT Product Calculation - Nominal}

Crucible Runs (glass basis)

Melt Rate Furnace Runs (glass basis) 500grams

Loading (oxide basis)
45 grams

$23.2 \%$

\begin{tabular}{|l|l|l|l|l|}
\hline & \multicolumn{4}{|c|}{ MB3 Baseline Feed } \\
\hline Processing & \multicolumn{4}{|c|}{ Nominal } \\
\hline Batch size & $\begin{array}{l}3 \text {-liter } \\
\text { Batch }\end{array}$ & $\begin{array}{l}15-\text { liter } \\
\text { Batch 1 }\end{array}$ & $\begin{array}{l}\text { 15-liter } \\
\text { Batch 2 }\end{array}$ & $\begin{array}{l}\text { 30-liter } \\
\text { Batch 3/4 }\end{array}$ \\
\hline Date & $10 / 11 / 00$ & $11 / 1 / 00$ & $11 / 20 / 00$ & $1 / 12 / 01$ \\
\hline Calcine Factor, \% & 15.1 & 15.44 & 15.76 & 15.38 \\
\hline $\begin{array}{l}\text { Amount Dried Solids } \\
\text { Produced, kg }\end{array}$ & 1.11 & 13.914 & 14.0 & 28.0 \\
\hline Melter Feed for Crucible Studies & 34.56 & 34.56 & 34.56 & 34.56 \\
\hline Amount of frit, g & 67.62 & 66.24 & 67.88 \\
\hline Amount of SRAT Product, g & 69.14 & 384.00 & 384.00 & 384.00 \\
\hline Melter Feed for Melt Rate Furnace Studies & 754.23 \\
\hline Amount of frit, g & 384.00 & 751.30 & 736.04 \\
\hline Amount of SRAT Product, g & 768.21 &
\end{tabular}

\footnotetext{
\# Based on analysis of sludge from experiments performed by David Koopman.
} 
WSRC-TR-2001-00126

Page 7 of 11

Table 3-- Melt Rate Furnace SRAT Product Calculation - Processing Alternatives

Crucible Runs (glass basis)

45 grams

Melt Rate Furnace Runs (glass basis) 500grams

Loading (oxide basis)

$23.2 \%$

\begin{tabular}{|l|l|l|l|}
\hline & \multicolumn{3}{|c|}{ Alternative Feeds } \\
\hline Processing & Formic Only & Overwashed & Underwashed \\
\hline Batch size & 3 -liter Batch & 3-liter Batch & 3-liter Batch \\
\hline Date & $12 / 15 / 00$ & $12 / 15 / 00$ & $12 / 15 / 00$ \\
\hline Calcine Factor, \% & 15.46 & 14.49 & 16.04 \\
\hline $\begin{array}{l}\text { Amount Dried Solids } \\
\text { Produced, kg }\end{array}$ & 2.385 & 2.386 & 2.442 \\
\hline Melter Feed for Crucible Studies & \\
\hline Amount of frit, g & 34.56 & 34.56 \\
\hline Amount of SRAT Product, g & 67.53 & 72.05 \\
\hline Melter Feed for Melt Rate Furnace Studies \\
\hline Amount of frit, g & 384.00 & 384.00 & 34.56 \\
\hline Amount of SRAT Product, g & 750.32 & 800.55 & 723.09 \\
\hline
\end{tabular}


WSRC-TR-2001-00126

Page 8 of 11

Figure 1 -- 22-Liter SRAT Vessel

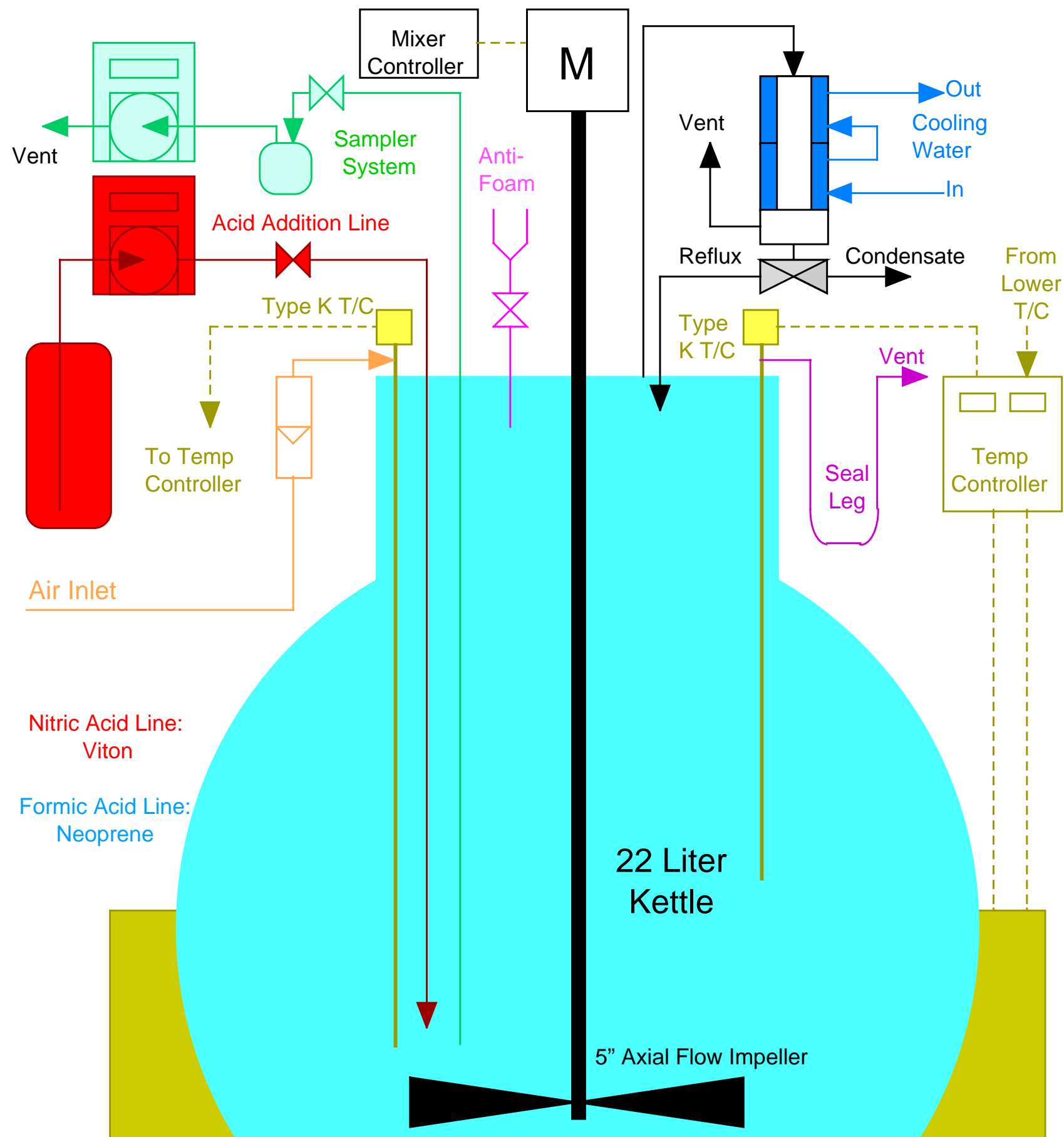

Dual Zone Mantle 
WSRC-TR-2001-00126

Page 9 of 11

Figure 2 -- Large SRAT Vessel

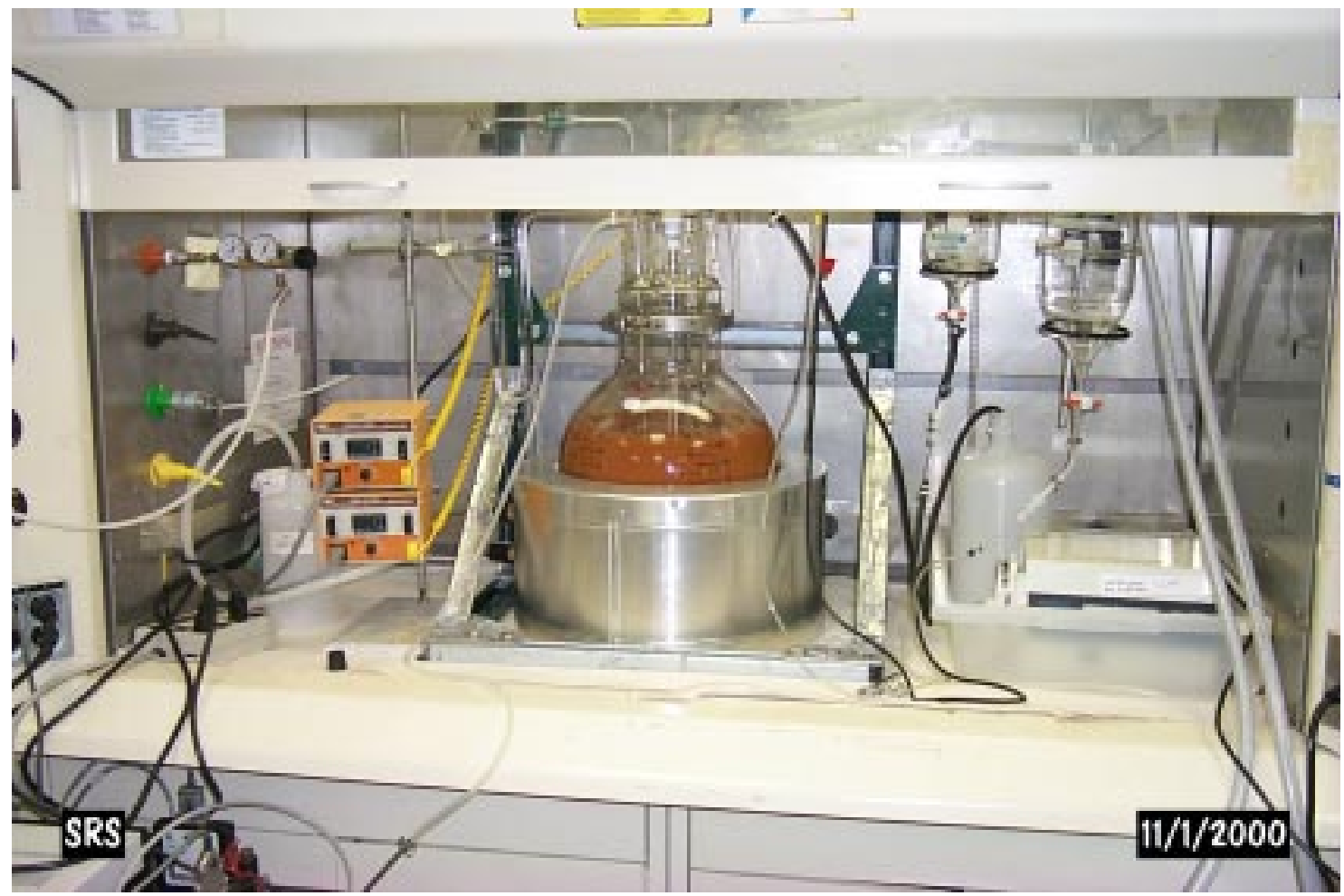

Figure 3 -- Large SRAT Vessel Upper Assembly

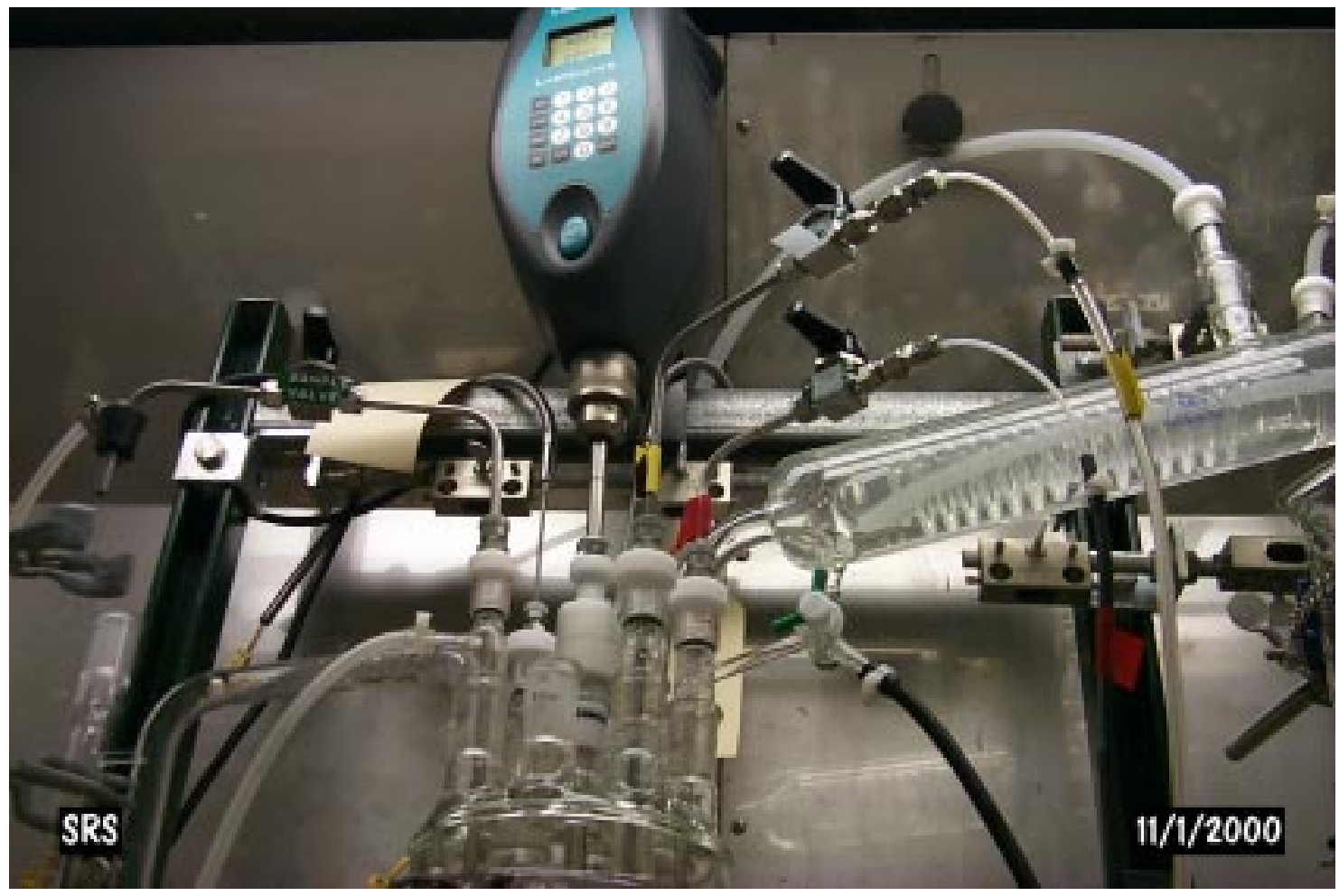


WSRC-TR-2001-00126

Page 10 of 11

\section{APPENDIX A: MACROBATCH 3 SRAT PRODUCT PREPARATION}

Appendix A-1 Macrobatch 3 SRAT Product Preparation for Melt Rate Tests: 15-Liter Batch (U), SRT-PTD-2000-00082, October 31, 2000.

Appendix A-2 Run Plan for Preparation of Macrobatch 3 Reducing SRAT Product for Melt Rate Tests (U), SRT-PTD-2000-00099, December 11, 2000.

Appendix A-3 Run Plan for Preparation of Macrobatch 3 Overwashed SRAT (U), SRTPTD-2000-00104, December 13, 2000.

Appendix A-4 Run Plan for Preparation of Macrobatch 3 Underwashed SRAT (U), SRTPTD-2000-00105, December 13, 2000.

\section{APPENDIX B: MACROBATCH 3 SLUDGE PREPARATION}

Appendix B-1 Run Plan for Preparation of Macrobatch 3 Overwashed Sludge (U), SRT-PTD-2000-00097, December 7, 2000.

Appendix B-2 Run Plan for Preparation of Macrobatch 3 Underwashed Sludge (U), SRT-PTD-2000-00098, December 7, 2000. 


\subsection{REFERENCES}

${ }^{1}$ WSRC.TR-2000-0395, DWPF Macrobatch 2 Melt Rate Tests, M. E. Stone, D. P. Lambert, October 5, 2000.

2 Technical Task Request \#HLW/DWPF/TTR-00-0044, DWPF Macrobatch 3 Melt Rate Study.

3 WSRC-RP-2001-00183, Increase Melting Rate of DWPF Feed -- Task Technical \& QA Plan, D. P. Lambert, D. K. Peeler, November 13, 2000 (first issued as WSRC-RP-2000-00080). TFA TTP\# SR-1-6-WT-31

${ }^{4}$ WSRC-TR-2000-00398, Revision 0, Sludge Batch 2 (Macrobatch 3) Flowsheet Studies With Simulants (U), D. C. Koopman, October 9, 2000.

5 HLW-SDT-2000-00128, Revision 0, Position Paper on Sludge Batch 2 Qualification Strategy and Simulant Composition, May 9, 2000.

6 SRT-WHM-2000-004, Rev. 0, 1, and 2, Specification for the Procurement of Tank 40 and Tank 8 Sludge Feed Simulants, M. R. Poirier, June 29, 2000.

7 Manual L27, Procedure 2.02, Rev 0, Laboratory Scale Chemical Process Cell Simulations, June 8, 1998.

${ }^{8}$ Lab notebooks WSRC-NB-2000-00106 and WSRC-NB-2001-00009.

9 WSRC-TR-2000-00211, Rev. 2, Technical Basis for the 242-16H Evaporator Cleaning Process, C. S. Boley, M. C. Thompson, W. R. Wilmarth, K. G. Brown, December 6, 2000. 
October 31, 2000

To: $\quad$ S. L. Marra, 704-1T

From: M. E.Stone, 704-1T MMS/C

Macrobatch 3 SRAT Product Preparation for Melt Rate Tests: 15-Liter Batch (U)

Reference: SRT-PTD-2000-0071, Run Plan for Preparation of Macrobatch 3 SRAT Product for Melt Rate Tests: 3-Liter Batch (U), October 5, 2000.

This document provides the necessary instructions for preparation of Slurry Mix Evaporator Tank (SRAT) product to be utilized during melt rate tests on Macrobatch 3 sludge simulant. Macrobatch 3 is assumed to be a $48 \%$ Tank 8 and 52\% Tank 40 blend (based on air-dried solids content). The 22-liter laboratory scale SRAT kettle will be configured as shown in Attachment One. The calculations are based on SRT-PTD-20000071 and a scaling factor of 6:1. Acid additions also take into account a 2:1 dilution factor which will be used to increase the acid flowrate to allow subsurface feeding.

Samples of the slurry will be taken after the initial boil down, after refluxing, and at the completion of the run.

The following sequence will be utilized to process the sludge:

SRAT Cycle Sequence

NOTE: Sufficient rinse water should be used after each addition to ensure complete transfer of the material added. Record amount of each rinse water addition in the laboratory notebook.

1. Verify that adequate formic and nitric acid is available and that sample results for the acid match the molarities shown in Table 2.

2. Weight out the required amounts of nitric acid and formic acid and dilute each with the amounts of dilution water shown in Table 1.

3. Verify that leak checks are complete on experimental apparatus.

4. Transfer amount of Tank 40 sludge to SRAT kettle shown in Table 1.

5. Transfer amount of Tank 8 sludge to SRAT kettle shown in Table 1.

6. Turn on SRAT agitator at speed indicated in Table 2 .

7. Turn on air purge to SRAT kettle at flowrate indicated in Table 2.

8. Add trim chemicals to SRAT kettle in amounts shown in Table 1. 
October 31, 2000

Page 2 of 4

9. Turn on cooling water to SRAT condensor at temperature shown in Table 2.

10. Add initial amount of antifoam to slurry in amount shown in Table 2.

11. Turn on mantle to heat vessel to temperature indicated in Table 2 for acid additions.

12. Once acid addition temperature is reached, add nitric acid as shown in Table 2.

- Add required amount of nitric acid to nitric acid addition funnel

- Open nitric acid addition valve.

- Pump nitric acid into kettle at flowrate shown in Table 2.

- Rinse nitric acid addition funnel with $25 \mathrm{ml}$ of DI water.

13. When nitric acid addition is complete, add formic acid as shown in Table 2.

- Add required amount of formic acid to formic acid addition funnel

- Open formic acid addition valve.

- Pump formic acid into kettle at flowrate shown in Table 2.

- Rinse formic acid addition funnel with $25 \mathrm{ml}$ of DI water.

14. If required, adjust agitator speed to maintain mixing.

15. When addition is complete, bring kettle to boiling by setting temperature controllers to the boilup temperature shown in Table 2 and add antifoam in same amount as initial addition, as shown in Table 2.

16. If required, reset agitator speed to value shown in Table 2.

17. Dewater the kettle by removing the amount of condensate specified by researcher.

18. Reflux the kettle for the time specified in Table 2.

19. Dewater the amount of condensate specified in Table 2.

20. Turn off mantle and allow SRAT kettle to cool overnight.

21. Turn off remaining equipment when vessel cools below boiling.

22. Transfer SRAT contents to a poly-bottle labeled as follows plus the date and time the bottle is filled.

Macrobatch 3 SRAT Product for Melt Rate Tests

Tank 8/40 Blend

Sodium Added as Formate and Nitrate

Predicted Redox: 0.2 (Baseline Process)

23. Housekeep after completion of run.

- Disassemble apparatus and remove from hood.

- Clean all glassware and other items in contact with sludge.

- Store all equipment in proper location.

- Wipe down hood and replace floor liner.

- Dispose of waste properly.

c: $\quad$ L. F. Landon, 704-1T

D. P. Lambert, 704-1T

D. C. Witt, 704-1T

D. K. Peeler, 773-43A

D. C. Koopman, 704-1T

T. H. Loirer, 773-23A 
SRT-PTD-2000-00082

October 31, 2000

Page 3 of 4

Table 1. Sludge and Trim Chemical Additions

\begin{tabular}{|l|c|}
\hline Chemical & $\begin{array}{c}\text { Addition Amount } \\
\text { (grams) }\end{array}$ \\
\hline Tank 40 Sludge Simulant & 8,400 \\
\hline Tank 8 Simulant & 8,400 \\
\hline Silver Nitrate & 5.2446 \\
\hline Palladium Nitrate Hydrate & 16.6800 \\
\hline Rhodium Nitrate Dihydrate & 7.8084 \\
\hline Ruthenium Chloride & 12.8364 \\
\hline Nickel Chloride Hexahydrate & 18.96 \\
\hline Sodium Formate & 216.06 \\
\hline Sodium Nitrate & 92.22 \\
\hline Manganese Oxide (85\%) & 36.28 \\
\hline
\end{tabular}

Table 2. Operating Parameters

\begin{tabular}{|l|c|c|}
\hline Parameter & Value & Units \\
\hline Antifoam Amount (IIT 747, 10\%) & 21 & $\mathrm{ml}$ \\
\hline Nitric Acid Amount (10.15 molar) & 90.6 & $\mathrm{ml}$ \\
\hline Nitric Acid Dilution Water & 90.6 & $\mathrm{ml}$ \\
\hline Nitric Acid Flowrate & 12.0 & $\mathrm{ml} / \mathrm{min}$ \\
\hline Formic Acid Amount (22.64 molar) & 533.4 & $\mathrm{ml}$ \\
\hline Formic Acid Dilution Water & 533.4 & $\mathrm{ml}$ \\
\hline Formic Acid Flowrate & $12.0 *$ & $\mathrm{ml} / \mathrm{min}$ \\
\hline Reflux Time & 8 & hours \\
\hline Final Dewater Volume & 3000 & grams \\
\hline Air Purge Rate & 3000 & $\mathrm{ml} / \mathrm{min}$ \\
\hline Agitator Speed & $200 \#$ & $\mathrm{RPM}$ \\
\hline $\begin{array}{l}\text { Condensor Cooling Water } \\
\text { Temperature }\end{array}$ & 15 & ${ }^{\circ} \mathrm{C}$ \\
\hline $\begin{array}{l}\text { Acid Addition Temperature (Upper } \\
\text { Zone) }\end{array}$ & 88 & ${ }^{\circ} \mathrm{C}$ \\
\hline $\begin{array}{l}\text { Acid Addition Temperature (Lower } \\
\text { Zone) }\end{array}$ & 93 & ${ }^{\circ} \mathrm{C}$ \\
\hline Boil-up Temperature (Both Zones) & 110 & ${ }^{\circ} \mathrm{C}$ \\
\hline
\end{tabular}

* Flowrate adjustments and antifoam additions should be used to minimize foaming. \# Agitator speed should be adjusted to maintain well mixed batch. 
S. L. Marra

Appendix A -1

WSRC-TR-2001-00126

SRT-PTD-2000-00082

Page A1-4 of A1-4

October 31, 2000

Page 4 of 4

\section{Attachment One. SRAT Kettle Equipment Setup}

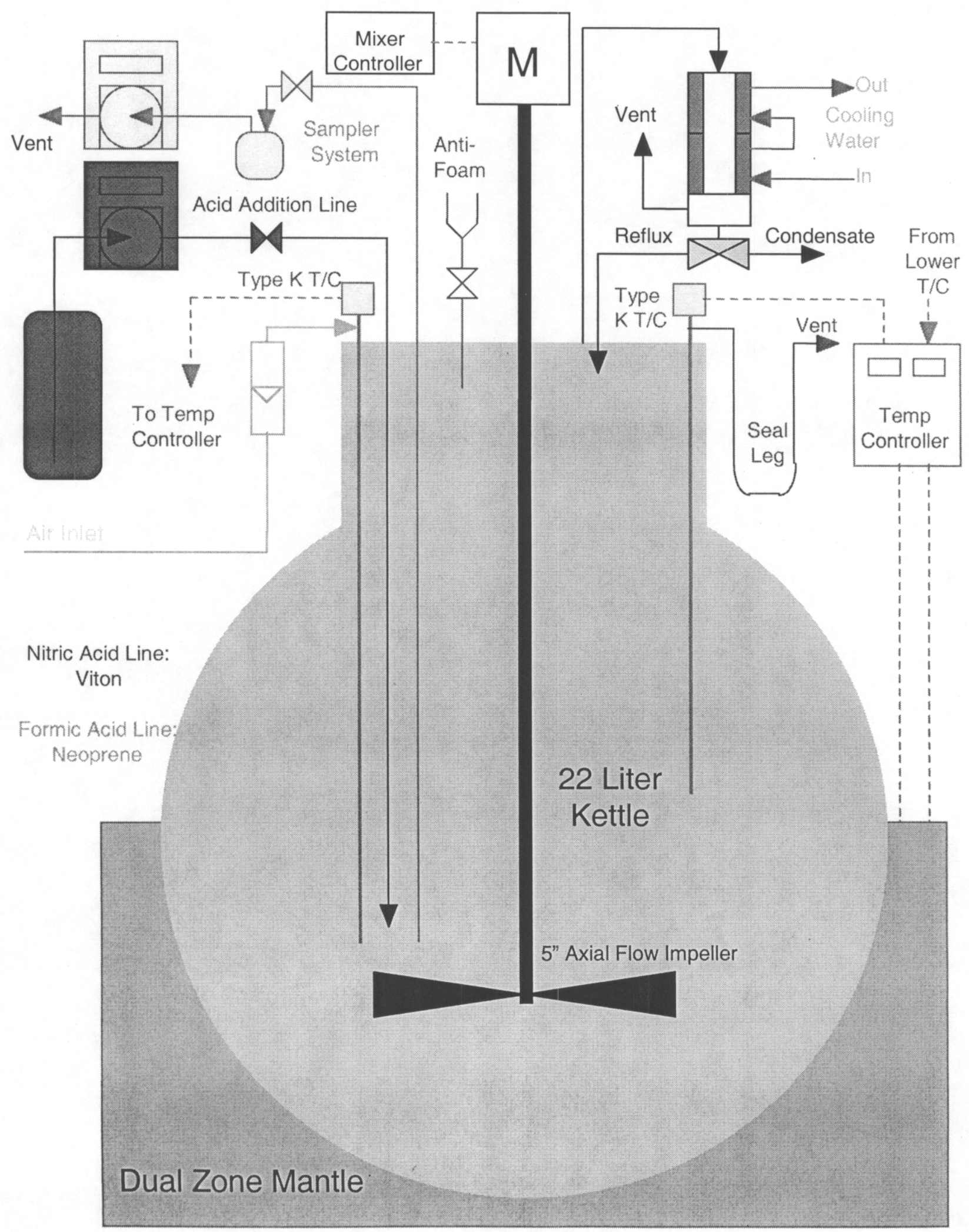


December 11, 2000

$\begin{array}{ll}\text { To: } & \text { S. L. Marra, 704-1T } \\ \text { From: } & \text { M. E.Stone, 704-1T } M C\end{array}$

\section{Run Plan for Preparation of Macrobatch 3 Reducing SRAT Product for Melt Rate Tests (U)}

This document provides the necessary instructions for preparation of reducing Slurry Receipt and Adjustment Tank (SRAT) product to be utilized during melt rate tests on Macrobatch 3 sludge simulant. Macrobatch 3 is assumed to be a $48 \%$ Tank 8 and $52 \%$ Tank 40 blend (based on air-dried solids content). Formic acid will be used to adjust the sludge to provide a feed that is as reducing as possible. The four liter laboratory scale SRAT kettle will be configured as shown in Attachment One.

The noble metal additions are based on the chemical process cell tests for this sludge, as documented in SRT-PTD-2000-48. No mercury will be added due to offgas concerns when the material is vitrified. Manganese oxide and nickel chloride additions are based on the baseline run, as documented in SRT-PTD2000-0071. Calculation of the sodium formate and sodium nitrate additions is shown in Attachment Two. The amount of formic acid required is calculated in Attachment Three.

Samples $(30 \mathrm{ml})$ will be pulled of the sludge prior to acid additions, after completion of the acid additions, after 4 hours of reflux, at the completion of the 8 hours of reflux, and at the completion of the run to allow an evaluation of the manganese oxide.

The following sequence will be utilized to process the sludge:

\section{SRAT Cycle Sequence}

1. Verify that adequate formic is available and that sample results for the acid match the molarity shown in Table 1.

2. Verify that leak checks are complete on experimental apparatus.

3. Transfer 1,400 grams of Tank 40 sludge to SRAT kettle.

4. Transfer 1,400 grams of Tank 8 sludge to SRAT kettle.

5. Turn on SRAT agitator at speed indicated in Table 2 .

6. Turn on air purge to SRAT kettle at flowrate indicated in Table 2.

7. Add trim chemicals to SRAT kettle in amounts shown in Table 1.

8. Turn on cooling water to SRAT condensor at temperature shown in Table 2.

9. Add initial amount of antifoam to slurry in amount shown in Table 2 .

10. Turn on mantle to heat vessel to temperature indicated in Table 2 for acid additions.

11. Add formic acid as shown in Table 2.

12. If required, adjust agitator speed to maintain mixing.

13. When addition is complete, bring kettle to boiling by setting temperature controller to the boilup temperature shown in Table 2.

14. Dewater to remove the amount of condensate specified by researcher.

15. Reflux the kettle for the time specified in Table 2.

16. Dewater the amount specified in Table 2.

17. Turn off mantle and allow SRAT kettle to cool.

18. Turn off remaining equipment. 
19. Transfer SRAT contents to a poly-bottle labeled as follows plus the date and time the bottle is filled.

Macrobatch 3 Reducing SRAT Product for Melt Rate Tests

Tank $8 / 40$ Blend

Predicted Redox: 0.26

Table 1. Sludge and Trim Chemical Additions

\begin{tabular}{|l|c|}
\hline Chemical & $\begin{array}{c}\text { Addition Amount } \\
\text { (grams) }\end{array}$ \\
\hline Tank 40 Sludge Simulant & 1,400 \\
\hline Tank 8 Simulant & 1,400 \\
\hline Silver Nitrate & 0.8741 \\
\hline Palladium Nitrate Hydrate & 2.7800 \\
\hline Rhodium Nitrate Dihydrate & 1.3014 \\
\hline Ruthenium Chloride & 2.1394 \\
\hline Nickel Chloride Hexahydrate & 3.16 \\
\hline Sodium Formate & 29.67 \\
\hline Sodium Nitrate & 23.29 \\
\hline Manganese Oxide (85\%) & 6.047 \\
\hline
\end{tabular}

Table 2. Operating Parameters

\begin{tabular}{|l|c|c|}
\hline Parameter & Value & Units \\
\hline Antifoam Amount (IIT 747, 10\%) & 3.5 & grams \\
\hline Formic Acid Molarity & 22.64 & $\mathrm{molar}$ \\
\hline Formic Acid Amount & 95.67 & $\mathrm{ml}$ \\
\hline Formic Acid Flowrate & $1.0^{*}$ & $\mathrm{ml} / \mathrm{min}$ \\
\hline Initial Dewater Volume & TBD & liters \\
\hline Reflux Time & 8 & hours \\
\hline Final Dewater Volume & 500 & $\mathrm{ml}$ \\
\hline Air Purge Rate & 500 & $\mathrm{ml} / \mathrm{min}$ \\
\hline Agitator Speed & 200 & $\mathrm{RPM}$ \\
\hline Condensor Cooling Water Temperature & 10 & ${ }^{\circ} \mathrm{C}$ \\
\hline Acid Addition Temperature & 93 & ${ }^{\circ} \mathrm{C}$ \\
\hline Boil-up Temperature & 115 & ${ }^{\circ} \mathrm{C}$ \\
\hline
\end{tabular}

* Flowrate adjustments and antifoam additions should be used to minimize foaming.

c:
D. P. Lambert, 704-1T:
D. C. Witt, 704-1T
M. F. Williams, 704-1T
PTD Files

D. K. Peeler, 773-43A

T. H. Loirer, 773-23A

J. E. Josephs, 704-1T

Melt Rate Laboratory Notebook 
WSRC-TR-2001-00126

Page A2-3 of A2-5

SRT-PTD-2000-0099

December 11, 2000

Page 3 of 5

Attachment One. SRAT Kettle Equipment Setup

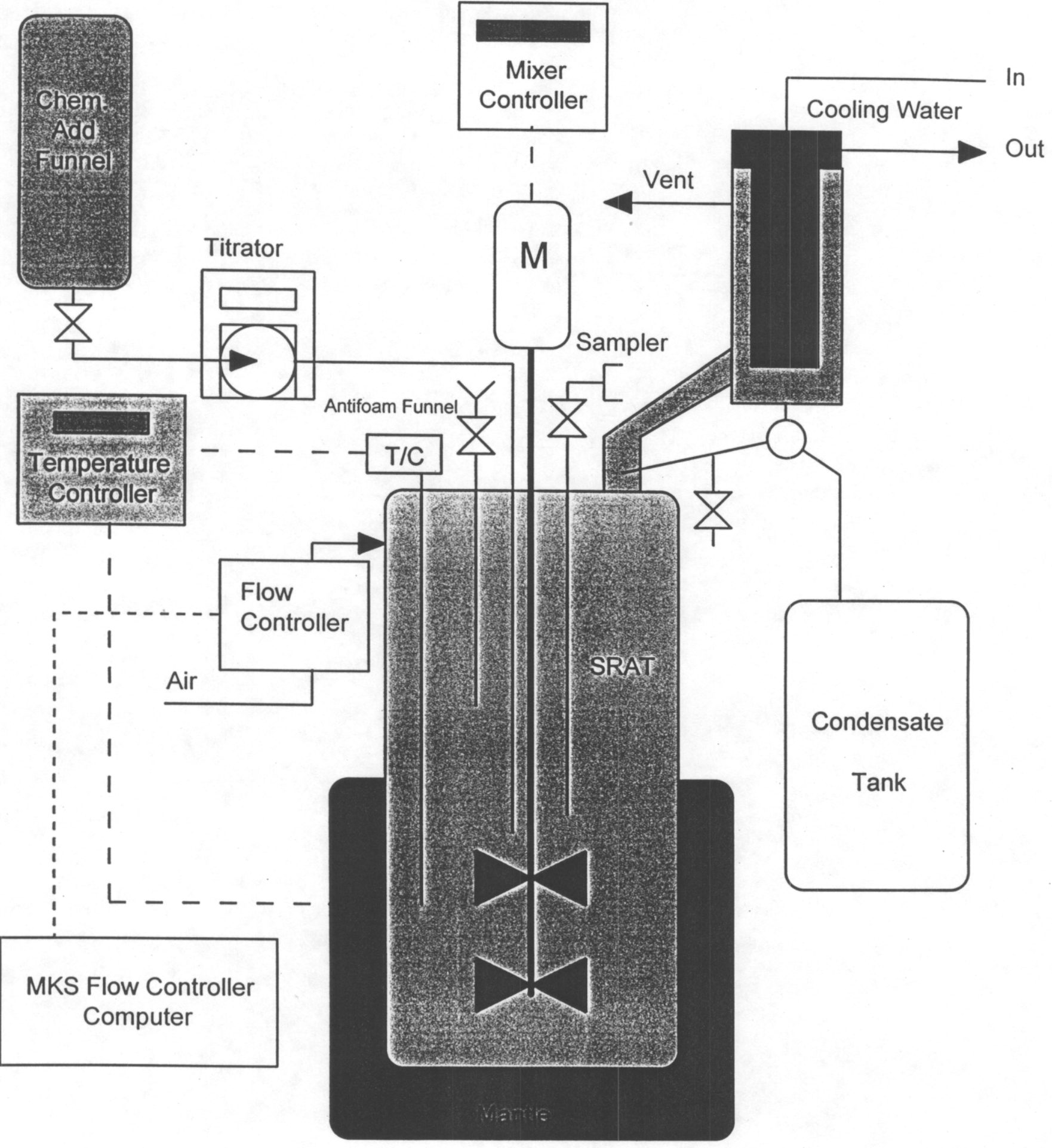


SRT-PTD-2000-0099

December 11, 2000

Page 4 of 5

Attachment Two. Sodium Formate Addition Calculations

\begin{tabular}{|l|c|c|l|l|c|c|}
\hline \multicolumn{3}{|c}{ Sodium Adjustment } & & \multicolumn{3}{c|}{ Redox Prediction } \\
\hline & Value & Units & & \multicolumn{2}{c|}{ Value } & Units \\
\hline Initial concentration & 6.04 & wt \% & & SRAT Formic Acid Addition & 95.67 & $\mathrm{ml}$ \\
\hline Desired concentration & 9.47 & wt \% & & SME Formic Acid Addition & 0.0000 & $\mathrm{ml}$ \\
\hline Sludge Quantity & 2800.00 & grams & & Formic Acid Concentration & 22.64 & $\mathrm{molar}$ \\
\hline Sludge Volume & 2.523 & liters & & Formic Acid Destruction & 35 & $\%$ \\
\hline Solids Loading & 15.40 & wt \% & & Formate from Formic Acid & 1.408 & $\mathrm{moles}$ \\
\hline Sodium Mol. Wt. & 23.00 & g/mol & & Nitric Acid & 0.00 & $\mathrm{ml}$ \\
\hline Initial Amount of Na & 26.04 & grams & Nitric Acid Concentration & 10.15 & $\mathrm{molar}$ \\
\hline Sodium Addition & 0.71 & moles & & Sludge Nitrite Concentration & 8500 & $\mathrm{mg} / \mathrm{kg}$ \\
\hline Final Concentration & 9.47 & wt \% & & Sludge Nitrate Concentration & 3800 & $\mathrm{mg} / \mathrm{kg}$ \\
\hline Ratio of Formate/Total & 0.6143 & g/g & & Conversion - Nitrite to Nitrate & 35 & $\%$ \\
\hline Amount of Sodium Formate & 0.4363 & moles & Sludge Density & 1.11 & $\mathrm{~kg} / \mathrm{L}$ \\
\hline Amount of Sodium Nitrate & 0.2740 & moles & Nitrate from Sludge & 0.306 & $\mathrm{moles}$ \\
\hline Sodium Formate Addition & $\mathbf{2 9 . 6 7}$ & grams & Redox & $0.255 \cdot$ & Fe+2/Fe \\
\hline Sodium Nitrate Addition & $\mathbf{2 3 . 2 9}$ & grams & & ${ }^{*}$ Redox Calculated per WSRC-RP-97-34 \\
\hline
\end{tabular}


WSRC-TR-2001-00126

S. L. Marra

Page A2-5 of A2-5

SRT-PTD-2000-0099

December 11, 2000

Page 5 of 5

Attachment Three. Calculation of Formic Acid Addition

\begin{tabular}{|c|c|c|c|c|c|c|}
\hline Raw Sludge Parameters & & & Stoichiometri & Acid & Actual Acid & \\
\hline & & & & & & \\
\hline Weight \% Solids & 15.40 & $w t \%$ of sludge & & Moles / L & Moles / L & \\
\hline Density & 1.11 & $\mathrm{~kg} / \mathrm{L}$ sludge & & & & \\
\hline Nitrite & 8500 & $\mathrm{mg} /(\mathrm{kg}$ sludge $)$ & Nitrite & 0.1538 & & \\
\hline Nitrate & 3800 & $\mathrm{mg} /(\mathrm{kg}$ sludge $)$ & & & & \\
\hline Manganese ( $\%$ of solids) & 2.520 & wt $\%$ of solids & $\mathrm{Mn}$ & 0.0941 & & \\
\hline TIC (Carbonate) & 0.000 & $\mathrm{mg} / \mathrm{L}$ & TIC & 0.0000 & & \\
\hline Hydroxide & 0.439 & Molar (sludge) & $\mathrm{OH}-$ & 0.4390 & & \\
\hline Mercury ( $\%$ of solids) & 0.000 & $w t \%$ & $\mathrm{Hg}$ & 0.0000 & & \\
\hline & & & Total & 0.6869 & 0.8587 & \\
\hline Assumed Parameters & & & & & & \\
\hline & & & Redox Deter & ination & & \\
\hline Conversion of nitrite to nitrate & 35.00 & $\%$ & & & Moles & \\
\hline Destruction of formate & 35.00 & $\%$ & & & & \\
\hline Overall Acid Stoichiometry & 125.00 & $\%$ & Formic Amol & & 0.859 & \\
\hline Nitric Acid Molarity & 10.15 & Molar & Nitric Amoun & & 0.000 & \\
\hline Formic Acid Molarity & 22.64 & Molar & Nitrate from I & itrite & 0.0718 & \\
\hline & & & Nitrate (w/o I & a addition) & 0.1398 & \\
\hline Redox Target & 0.200 & $\mathrm{Fe}+2 / \mathrm{Fe}$ & Predicted $\mathrm{Re}$ & $0 x^{*}$ & 0.255 & \\
\hline Ratio of Formic to Total Acid & 1.000 & mole / mole & * Redox Calc & lated per V & NSRC-RP-97 & \\
\hline Molecular Weights & & & & & & \\
\hline & & & & & & \\
\hline Nitrite & 46.00 & $\mathrm{~g} / \mathrm{mole}$ & Acid Volume & & $\mathrm{ml} / \mathrm{L}$ & \\
\hline Nitrate & 62.00 & $\mathrm{~g} / \mathrm{mole}$ & & & & \\
\hline Manganese & 54.94 & $\mathrm{~g} / \mathrm{mole}$ & Formic Acid & & 37.926 & \\
\hline Carbonate & 60.01 & $\mathrm{~g} / \mathrm{mole}$ & Nitric Acid & & 0.000 & \\
\hline Mercury & 200.60 & $\mathrm{~g} / \mathrm{mole}$ & & & & \\
\hline Factors for Acid Calculation ${ }^{*}$ & & & Batch Calcul & tions & & \\
\hline & & & & & & \\
\hline Acid Requirement for Nitrites & 0.75 & mole / mole & Batch Size & & 2.52 & liters \\
\hline Acid Requirement for $\mathrm{Mn}$ & 1.20 & mole / mole & Batch Weigh & & 2.800 & $\mathrm{~kg}$ \\
\hline Acid Requirement for $\mathrm{Hg}$ & 1.00 & mole / mole & Formic Acid & ddition & 95.6698 & $\mathrm{ml}$ \\
\hline Acid Requirement for Hydroxide & 1.00 & mole / mole & Nitric Acid Ac & dition & 0.0000 & $\mathrm{ml}$ \\
\hline Acid Requirement for Carbonate & 2.00 & mole / mole & & & & \\
\hline 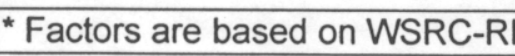 & $92-1056$ & & & & & \\
\hline
\end{tabular}


WESTINGHOUSE SAVANNAH RIVER COMPANY INTEROFFICE MEMORANDUM

SRT-PTD-2000-0104

December 13, 2000

To: $\quad$ S. L. Marra, 704-1T

From: M. E.Stone, 704-1T MML 1 C

\section{Run Plan for Preparation of Macrobatch 3 Overwashed SRAT Product (U)}

This document provides the necessary instructions for preparation of reducing Slurry Receipt and Adjustment Tank (SRAT) product to be utilized during melt rate tests on Macrobatch 3 sludge simulant. Macrobatch 3 is assumed to be a $48 \%$ Tank 8 and 52\% Tank 40 blend (based on air-dried solids content). Formic acid will be used to adjust the sludge to provide a feed that is as reducing as possible. The four liter laboratory scale SRAT kettle will be configured as shown in SRT-PTD-2000-00097.

The noble metal additions, manganese oxide and nickel were added per SRT-PTD-2000-0097. Calculation of the sodium formate and sodium nitrate additions is shown in Table Three. The amounts of nitric and formic acid required is calculated in Attachment One. Two samples $(30 \mathrm{ml})$ will be pulled of the sludge at the completion of the run.

The following sequence will be utilized to process the sludge:

SRAT Cycle Sequence

1. Verify that adequate formic and nitric acid is available and that sample results for the acid match the molarity shown in Table 1.

2. Turn on SRAT agitator at speed indicated in Table 2 .

3. Turn on air purge to SRAT kettle at flowrate indicated in Table 2.

4. Add trim chemicals to SRAT kettle in amounts shown in Table 1.

5. Turn on cooling water to SRAT condensor at temperature shown in Table 2.

6. Add initial amount of antifoam to slurry in amount shown in Table 2.

7. Turn on mantle to heat vessel to temperature indicated in Table 2 for acid additions.

8. Add nitric acid as shown in Table 2 .

9. Add formic acid as shown in Table 2 .

10. If required, adjust agitator speed to maintain mixing.

11. When addition is complete, bring kettle to boiling by setting temperature controller to the boilup temperature shown in Table 2.

12. Dewater to remove the amount of condensate specified by researcher.

13. Reflux the kettle for the time specified in Table 2.

14. Dewater the amount specified in Table 2.

15. Turn off mantle and allow SRAT kettle to cool.

16. Turn off remaining equipment.

17. Transfer SRAT contents to a poly-bottle labeled as follows plus the date and time the bottle is filled.

Macrobatch 3 Overwashed SRAT Product for Melt Rate Tests

Tank $8 / 40$ Blend

Predicted Redox: 0.20 
WSRC-TR-2001-00126

SRT-PTD-2000-0104

Page A3-2 of A3-3

December 13, 2000

Page 2 of 3

Table 1. Sludge and Trim Chemical Additions

\begin{tabular}{|l|c|}
\hline Chemical & $\begin{array}{c}\text { Addition Amount } \\
\text { (grams) }\end{array}$ \\
\hline Sodium Formate & 36.50 \\
\hline Sodium Nitrate & 14.75 \\
\hline
\end{tabular}

Table 2. Operating Parameters

\begin{tabular}{|l|c|c|}
\hline Parameter & Value & Units \\
\hline Antifoam Amount (IIT 747, 10\%) & 3.5 & grams \\
\hline Nitric Acid Molarity & 10.15 & Molar \\
\hline Nitric Acid Amount & 17.01 & Ml \\
\hline Nitric Acid Flowrate & 1.0 & $\mathrm{ml} / \mathrm{min}$ \\
\hline Formic Acid Molarity & 22.64 & $\mathrm{molar}$ \\
\hline Formic Acid Amount & 65.62 & $\mathrm{ml}$ \\
\hline Formic Acid Flowrate & $1.0 *$ & $\mathrm{ml} / \mathrm{min}$ \\
\hline Initial Dewater Volume & $\mathrm{TBD}$ & liters \\
\hline Reflux Time & 8 & hours \\
\hline Final Dewater Volume & 500 & $\mathrm{ml}$ \\
\hline Air Purge Rate & 500 & $\mathrm{ml} / \mathrm{min}$ \\
\hline Agitator Speed & 200 & $\mathrm{RPM}$ \\
\hline Condensor Cooling Water Temperature & 10 & ${ }^{\circ} \mathrm{C}$ \\
\hline Acid Addition Temperature & 93 & ${ }^{\circ} \mathrm{C}$ \\
\hline Boil-up Temperature & 115 & ${ }^{\circ} \mathrm{C}$ \\
\hline
\end{tabular}

* Flowrate adjustments and antifoam additions should be used to minimize foaming.

Table 3. Sodium Formate Addition Calculations

\begin{tabular}{|c|c|c|c|c|c|}
\hline \multicolumn{3}{|c|}{ Insoluble Sodium Adjustment } & \multicolumn{3}{|c|}{ Redox Prediction } \\
\hline & Value & Units & & Value & Units \\
\hline Initial concentration & $6.04 \%$ & wt $\%$ & SRAT Formic Acid Addition & 65.62 & $\mathrm{ml}$ \\
\hline Desired concentration & $9.47 \%$ & wt \% & SME Formic Acid Addition & 0.0000 & $\overline{\mathrm{ml}}$ \\
\hline Sludge Quantity & 2800.00 & grams & Formic Acid Concentration & 22.64 & molar \\
\hline Sludge Volume & 2.523 & liters & Formic Acid Destruction & 35 & $\%$ \\
\hline Solids Loading & $15.40 \%$ & wt \% & Formate from Formic Acid & 0.966 & moles \\
\hline Sodium Mol. Wt. & 23.00 & $\mathrm{~g} / \mathrm{mol}$ & Nitric Acid & 17.01 & $\mathrm{ml}$ \\
\hline Initial Amount of $\mathrm{Na}$ & 26.04 & grams & Nitric Acid Concentration & 10.15 & molar \\
\hline Sodium Addition & 0.71 & moles & Sludge Nitrite Concentration & 4520 & $\mathrm{mg} / \mathrm{kg}$ \\
\hline Final Concentration & 9.47 & wt \% & Sludge Nitrate Concentration & 2650 & $\mathrm{mg} / \mathrm{kg}$ \\
\hline Ratio of Formate/Total & 0.7556 & $g / g$ & Conversion - Nitrite to Nitrate & 35 & $\%$ \\
\hline Amount of Sodium Formate & 0.5367 & moles & Sludge Density & 1.11 & $\mathrm{~kg} / \mathrm{L}$ \\
\hline Amount of Sodium Nitrate & 0.1736 & moles & Nitrate from Sludge & 0.191 & moles \\
\hline Sodium Formate Addition & 36.50 & grams & Redox & 0.200 & $\mathrm{Fe}+2 / \mathrm{Fe}$ \\
\hline Sodium Nitrate Addition & 14.75 & grams & ${ }^{\star}$ Redox Calculated per & RC-RP & $7-34$ \\
\hline
\end{tabular}
c: $\quad$ D. P. Lambert, 704-1T
D. C. Witt, 704-1T
M. F. Williams, 704-1T
D. K. Peeler, 773-43A
PTD Files
T. H. Loirer, 773-23A
J. E. Josephs, 704-1T
Melt Rate Laboratory Notebook 
S. L. Marra

SRT-PTD-2000-0104

December 13, 2000

Page 3 of 3
Appendix A-3

WSRC-TR-2001-00126

Page A3-3 of A3-3

Attachment One. Calculation of Formic Acid Addition

\begin{tabular}{|c|c|c|c|c|c|c|}
\hline Raw Sludge Parameters & & & Stoichiometri & Acid & Actual Acid & \\
\hline Weight \% Solids & 14.30 & wt $\%$ of sludge & & Moles / L & Moles / L & \\
\hline Density & 1.11 & $\mathrm{~kg} / \mathrm{L}$ sludge & & & & \\
\hline Nitrite & 4520 & mg / (kg sludge) & Nitrite & 0.0818 & & \\
\hline Nitrate & 2650 & mg / (kg sludge) & & & & \\
\hline Manganese (\% of solids) & 3.160 & wt $\%$ of solids & $\mathrm{Mn}$ & 0.1096 & & \\
\hline TIC (Carbonate) & 0.000 & $\mathrm{mg} / \mathrm{L}$ & $\mathrm{TIC}$ & 0.0000 & & \\
\hline Hydroxide & 0.335 & Molar (sludge) & $\mathrm{OH}-$ & 0.3346 & & \\
\hline Mercury ( $\%$ of solids) & 0.000 & $w t \%$ & $\mathrm{Hg}$ & 0.0000 & & \\
\hline & & & Total & 0.5259 & 0.6574 & \\
\hline Assumed Parameters & & & & & & \\
\hline & & & Redox Deterr & ination & & \\
\hline Conversion of nitrite to nitrate & 35.00 & $\%$ & & & Moles & \\
\hline Destruction of formate & 35.00 & $\%$ & & & & \\
\hline Overall Acid Stoichiometry & 125.00 & $\%$ & Formic Amou & & 0.589 & \\
\hline Nitric Acid Molarity & 10.15 & Molar & Nitric Amount & & 0.068 & \\
\hline Formic Acid Molarity & 22.64 & Molar & Nitrate from $\mathrm{N}$ & itrite & 0.0382 & \\
\hline & & $\therefore$ & Nitrate (w/o N & a addition) & 0.1541 & \\
\hline Redox Target & 0.200 & $\mathrm{Fe}+2 / \mathrm{Fe}$ & Predicted $\mathrm{Re}$ & $0 x^{*}$ & 0.200 & \\
\hline Ratio of Formic to Total Acid & 0.896 & mole / mole & * Redox Calc & lated per V & VSRC-RP-97 & \\
\hline Molecular Weights & & & & & & \\
\hline & & & & & & \\
\hline Nitrite & 46.00 & $\mathrm{~g} / \mathrm{mole}$ & Acid Volumes & & $\mathrm{ml} / \mathrm{L}$ & \\
\hline Nitrate & 62.00 & $\mathrm{~g} / \mathrm{mole}$ & & & & \\
\hline Manganese & 54.94 & $\mathrm{~g} / \mathrm{mole}$ & Formic Acid & & 26.014 & \\
\hline Carbonate & 60.01 & $\mathrm{~g} / \mathrm{mole}$ & Nitric Acid & & 6.744 & \\
\hline Mercury & 200.60 & $\mathrm{~g} / \mathrm{mole}$ & & & & \\
\hline Factors for Acid Calculation* & & & Batch Calcula & tions & & \\
\hline & & & & & & \\
\hline Acid Requirement for Nitrites & 0.75 & mole / mole & Batch Size & & 2.52 & liters \\
\hline Acid Requirement for $\mathrm{Mn}$ & 1.20 & mole / mole & Batch Weight & & 2.800 & $\mathrm{~kg}$ \\
\hline Acid Requirement for $\mathrm{Hg}$ & 1.00 & mole / mole & Formic Acid $A$ & ddition & 65.6217 & $\mathrm{ml}$ \\
\hline Acid Requirement for Hydroxide & 1.00 & mole / mole & Nitric Acid Ad & dition & 17.0108 & $\mathrm{ml}$ \\
\hline Acid Requirement for Carbonate & 2.00 & mole / mole & & & & \\
\hline${ }^{\star}$ Factors are based on WSRC-R & $2-1056$ & & & & & \\
\hline
\end{tabular}


WESTINGHOUSE SAVANNAH RIVER COMPANY

INTEROFFICE MEMORANDUM

SRT-PTD-2000-0105

December 13, 2000

To: $\quad$ S. L. Marra, 704-1T

From: M. E.Stone, 704-1T M/C

\section{$\underline{\text { Run Plan for Preparation of Macrobatch } 3 \text { Underwashed SRAT Product (U) }}$}

This document provides the necessary instructions for preparation of reducing Slurry Receipt and Adjustment Tank (SRAT) product to be utilized during melt rate tests on Macrobatch 3 sludge simulant. Macrobatch 3 is assumed to be a $48 \%$ Tank 8 and 52\% Tank 40 blend (based on air-dried solids content). Formic acid will be used to adjust the sludge to provide a feed that is as reducing as possible. The four liter laboratory scale SRAT kettle will be configured as shown in SRT-PTD-2000-00098.

The noble metal additions, manganese oxide and nickel were added per SRT-PTD-2000-0098. Calculation of the sodium formate and sodium nitrate additions is shown in Table Three. The amounts of nitric and formic acid required is calculated in Attachment One. Two samples $(30 \mathrm{ml})$ will be pulled of the sludge at the completion of the run.

The following sequence will be utilized to process the sludge:

\section{SRAT Cycle Sequence}

1. Verify that adequate formic and nitric acid is available and that sample results for the acid match the molarity shown in Table 1.

2. Turn on SRAT agitator at speed indicated in Table 2 .

3. Turn on air purge to SRAT kettle at flowrate indicated in Table 2.

4. Add trim chemicals to SRAT kettle in amounts shown in Table 1.

5. Turn on cooling water to SRAT condensor at temperature shown in Table 2.

6. Add initial amount of antifoam to slurry in amount shown in Table 2.

7. Turn on mantle to heat vessel to temperature indicated in Table 2 for acid additions.

8. Add nitric as shown in Table 2.

9. Add formic acid as shown in Table 2.

10. If required, adjust agitator speed to maintain mixing.

11. When addition is complete, bring kettle to boiling by setting temperature controller to the boilup temperature shown in Table 2.

12. Dewater to remove the amount of condensate specified by researcher.

13. Reflux the kettle for the time specified in Table 2.

14. Dewater the amount specified in Table 2.

15. Turn off mantle and allow SRAT kettle to cool.

16. Turn off remaining equipment.

17. Transfer SRAT contents to a poly-bottle labeled as follows plus the date and time the bottle is filled.

Macrobatch 3 Underwashed SRAT Product for Melt Rate Tests

Tank 8/40 Blend

Predicted Redox: 0.20 
December 13, 2000

Page 2 of 3

Table 1. Sludge and Trim Chemical Additions

\begin{tabular}{|l|c|}
\hline Chemical & $\begin{array}{c}\text { Addition Amount } \\
\text { (grams) }\end{array}$ \\
\hline Sodium Formate & 35.21 \\
\hline Sodium Nitrate & 16.37 \\
\hline
\end{tabular}

Table 2. Operating Parameters

\begin{tabular}{|l|c|c|}
\hline Parameter & Value & Units \\
\hline Antifoam Amount (IIT 747, 10\%) & 3.5 & grams \\
\hline Nitric Acid Molarity & 10.15 & molar \\
\hline Nitric Acid Amount & 11.14 & $\mathrm{ml}$ \\
\hline Nitric Acid Flowrate & 1.0 & $\mathrm{ml} / \mathrm{min}$ \\
\hline Formic Acid Molarity & 22.64 & $\mathrm{molar}$ \\
\hline Formic Acid Amount & 102.42 & $\mathrm{ml}$ \\
\hline Formic Acid Flowrate & $1.0 *$ & $\mathrm{ml} / \mathrm{min}$ \\
\hline Initial Dewater Volume & $\mathrm{TBD}$ & liters \\
\hline Reflux Time & 8 & hours \\
\hline Final Dewater Volume & 500 & $\mathrm{ml}$ \\
\hline Air Purge Rate & 500 & $\mathrm{ml} / \mathrm{min}$ \\
\hline Agitator Speed & 200 & $\mathrm{RPM}$ \\
\hline Condensor Cooling Water Temperature & 10 & ${ }^{\circ} \mathrm{C}$ \\
\hline Acid Addition Temperature & 93 & ${ }^{\circ} \mathrm{C}$ \\
\hline Boil-up Temperature & 115 & ${ }^{\circ} \mathrm{C}$ \\
\hline
\end{tabular}

* Flowrate adjustments and antifoam additions should be used to minimize foaming.

Table 3. Sodium Formate Addition Calculations

\begin{tabular}{|c|c|c|c|c|c|}
\hline \multicolumn{3}{|l|}{\begin{tabular}{|l|} 
Insoluble Sodium Adjustment \\
\end{tabular}} & \multicolumn{3}{|l|}{ Redox Prediction } \\
\hline & Value & Units & & Value & Units \\
\hline Initial concentration & $6.04 \%$ & wt \% & SRAT Formic Acid Addition & 102.42 & $\mathrm{ml}$ \\
\hline Desired concentration & $9.47 \%$ & wt $\%$ & SME Formic Acid Addition & 0.0000 & $\mathrm{ml}$ \\
\hline Sludge Quantity & 2800.00 & grams & Formic Acid Concentration & 22.64 & molar \\
\hline Sludge Volume & 2.523 & liters & Formic Acid Destruction & 35 & $\%$ \\
\hline Solids Loading & $15.40 \%$ & wt \% & Formate from Formic Acid & 1.507 & moles \\
\hline Sodium Mol. Wt. & 23.00 & $\mathrm{~g} / \mathrm{mol}$ & Nitric Acid & 11.14 & $\mathrm{ml}$ \\
\hline Initial Amount of $\mathrm{Na}$ & 26.04 & grams & Nitric Acid Concentration & 10.15 & molar \\
\hline Sodium Addition & 0.71 & moles & Sludge Nitrite Concentration & 9160 & $\mathrm{mg} / \mathrm{kg}$ \\
\hline Final Concentration & 9.47 & wt \% & Sludge Nitrate Concentration & 5890 & $\mathrm{mg} / \mathrm{kg}$ \\
\hline Ratio of Formate/Total & 0.7289 & $g / g$ & Conversion - Nitrite to Nitrate & 35 & $\%$ \\
\hline Amount of Sodium Formate & 0.5177 & moles & Sludge Density & 1.11 & $\mathrm{~kg} / \mathrm{L}$ \\
\hline Amount of Sodium Nitrate & 0.1926 & moles & Nitrate from Sludge & 0.411 & moles \\
\hline Sodium Formate Addition & 35.21 & grams & Redox & 0.200 & $\mathrm{Fe}+2 / \mathrm{Fe}$ \\
\hline Sodium Nitrate Addition & 16.37 & grams & \multicolumn{3}{|c|}{ * Redox Calculated per WSRC-RP-97-34 } \\
\hline
\end{tabular}

c: $\quad$ D. P. Lambert, 704-1T

D. C. Witt, 704-1T

M. F. Williams, 704-1T

PTD Files
D. K. Peeler, 773-43A

T. H. Loirer, 773-23A

J. E. Josephs, 704-1T

Melt Rate Laboratory Notebook 
S. L. Marra

SRT-PTD-2000-0105

Appendix A-4

December 13, 2000

Page 3 of 3
WSRC-TR-2001-00126

Page A4-3 of A4-3

Attachment One. Calculation of Formic Acid Addition

\begin{tabular}{|c|c|c|c|c|c|c|}
\hline \multirow[t]{2}{*}{ Raw Sludge Parameters } & & & \multicolumn{2}{|c|}{ Stoichiometric Acid } & \multirow[t]{2}{*}{ Actual Acid } & \\
\hline & & & & & & \\
\hline Weight \% Solids & 16.70 & wt $\%$ of sludge & & Moles / L & Moles / L & \\
\hline Density & 1.11 & $\mathrm{~kg} / \mathrm{L}$ sludge & & & & \\
\hline Nitrite & 9160 & mg / (kg sludge) & Nitrite & 0.1658 & & \\
\hline Nitrate & 5890 & mg / (kg sludge) & & & & \\
\hline Manganese (\% of solids) & 2.659 & wt $\%$ of solids & $\mathrm{Mn}$ & 0.1076 & & \\
\hline TIC (Carbonate) & 0.000 & $\mathrm{mg} / \mathrm{L}$ & TIC & 0.0000 & & \\
\hline Hydroxide & 0.498 & Molar (sludge) & $\mathrm{OH}-$ & 0.4978 & & \\
\hline \multirow[t]{2}{*}{ Mercury (\% of solids) } & 0.000 & $w t \%$ & $\mathrm{Hg}$ & 0.0000 & & \\
\hline & & & Total & 0.7712 & 0.9640 & \\
\hline \multicolumn{7}{|l|}{ Assumed Parameters } \\
\hline & & & \multicolumn{2}{|c|}{ Redox Determination } & & \\
\hline Conversion of nitrite to nitrate & 35.00 & $\%$ & & & Moles & \\
\hline Destruction of formate & 35.00 & $\%$ & & & & \\
\hline Overall Acid Stoichiometry & 125.00 & $\%$ & \multicolumn{2}{|c|}{ Formic Amount } & 0.919 & \\
\hline Nitric Acid Molarity & 10.15 & Molar & \multicolumn{2}{|c|}{ Nitric Amount } & 0.045 & \\
\hline \multirow[t]{2}{*}{ Formic Acid Molarity } & 22.64 & Molar & \multicolumn{2}{|c|}{ Nitrate from Nitrite } & 0.0774 & \\
\hline & & & \multicolumn{2}{|c|}{ Nitrate (w/o $\mathrm{Na}$ addition) } & 0.2276 & \\
\hline Redox Target & 0.200 & $\mathrm{Fe}+2 / \mathrm{Fe}$ & Predicted Re & $\mathrm{dox}^{*}$ & 0.200 & \\
\hline Ratio of Formic to Total Acid & 0.953 & mole / mole & \multicolumn{4}{|c|}{${ }^{*}$ Redox Calculated per WSRC-RP-97-34 } \\
\hline & & & & & & \\
\hline \multicolumn{7}{|l|}{ Molecular Weights } \\
\hline & & & & & & \\
\hline Nitrite & 46.00 & $\mathrm{~g} / \mathrm{mole}$ & \multicolumn{2}{|l|}{ Acid Volumes } & $\mathrm{ml} / \mathrm{L}$ & \\
\hline Nitrate & 62.00 & $\mathrm{~g} / \mathrm{mole}$ & & & & \\
\hline Manganese & 54.94 & $\mathrm{~g} / \mathrm{mole}$ & Formic Acid & & 40.601 & \\
\hline Carbonate & 60.01 & $\mathrm{~g} / \mathrm{mole}$ & Nitric Acid & & 4.417 & \\
\hline \multirow[t]{2}{*}{ Mercury } & 200.60 & $\mathrm{~g} / \mathrm{mole}$ & & & & \\
\hline & & & & & & \\
\hline Factors for Acid Calculation* & & & \multicolumn{2}{|c|}{ Batch Calculations } & & \\
\hline & & & & & & \\
\hline Acid Requirement for Nitrites & 0.75 & mole / mole & Batch Size & & 2.52 & liters \\
\hline Acid Requirement for $\mathrm{Mn}$ & 1.20 & mole / mole & \multicolumn{2}{|l|}{ Batch Weight } & 2.800 & $\mathrm{~kg}$ \\
\hline Acid Requirement for $\mathrm{Hg}$ & 1.00 & mole / mole & \multicolumn{2}{|c|}{ Formic Acid Addition } & 102.4165 & $\mathrm{ml}$ \\
\hline Acid Requirement for Hydroxide & 1.00 & mole / mole & \multicolumn{2}{|c|}{ Nitric Acid Addition } & 11.1432 & $\mathrm{ml}$ \\
\hline Acid Requirement for Carbonate & 2.00 & mole / mole & & & & \\
\hline \multicolumn{2}{|c|}{${ }^{\star}$ Factors are based on WSRC-RP-92-1056 } & & & & & \\
\hline
\end{tabular}




\section{WESTINGHOUSE SAVANNAH RIVER COMPANY INTEROFFICE MEMORANDUM}

SRT-PTD-2000-00097

December 7, 2000

To:

S. L. Marra, 704-1T

From: M.E.Stone, 704-1T MÉ $/($

\section{$\underline{\text { Run Plan for Preparation of Macrobatch } 3 \text { Overwashed Sludge (U) }}$}

This document provides the necessary instructions for preparation of Macrobatch 3 overwashed sludge to be utilized during melt rate tests on Macrobatch 3 sludge simulant. Macrobatch 3 is assumed to be a $48 \%$ Tank 8 and 52\% Tank 40 blend (based on air-dried solids content). The four liter laboratory scale SRAT kettle will be configured as shown in Attachment One. The basis for the washing sequence is shown in Attachment Two.

The sludge will be washed by the following sequence:

1. Addition of 2800 grams of Tank $8 / 40$ Blend sludge to vessel.

2. Allow solids to settle.

3. Decant $500^{*} \mathrm{ml}$ of supernate from vessel.

4. Add 1075 grams of DI water to vessel.

5. Mix contents of vessel thoroughly.

6. Allow solids to settle.

7. Decant $1075 \mathrm{ml}$ of supernate from vessel.

8. Add 500 grams of DI water to vessel.

* If $500 \mathrm{ml}$ of supernate cannot be removed, contact researcher for instructions.

After washing, the sludge will be trimmed as shown in Table 1. The noble metal additions are based on the chemical process cell tests for this sludge, as documented in SRT-PTD-2000-48 and shown in Table 1. No mercury will be added due to offgas concerns when the material is vitrified. Addition of the manganese oxide and nickel chloride hexahydrate are based on the 3L baseline run, as documented in SRT-PTD-20000071.

Table 1. Trim Chemical Additions

\begin{tabular}{|l|c|}
\hline Chemical & $\begin{array}{c}\text { Addition Amount } \\
\text { (grams) }\end{array}$ \\
\hline Silver Nitrate & 0.8741 \\
\hline Palladium Nitrate Hydrate & 2.7800 \\
\hline Rhodium Nitrate Dihydrate & 1.3014 \\
\hline Ruthenium Chloride & 2.1394 \\
\hline Nickel Chloride Hexahydrate & 3.16 \\
\hline Manganese Oxide (85\%) & 6.047 \\
\hline
\end{tabular}

After trim chemical addition, the sludge will be mixed thoroughly and a $40 \mathrm{ml}$ sample pulled. Analysis of the sample must be expedited to allow the acid addition calculations to be performed.
c: $\quad$ L. F. Landon, 704-1T
D. K. Peeler, 773-43A
D. P. Lambert, 704-1T
D. C. Witt, 704-1T
J. E. Joseph, 704-1T
D. C. Koopman, 704-1T
T. H. Loirer, 773-23A
PTD Files
Melt Rate Notebook 
S. L. Marra

SRT-PTD-2000-0097

December 7, 2000

Page 2 of 3

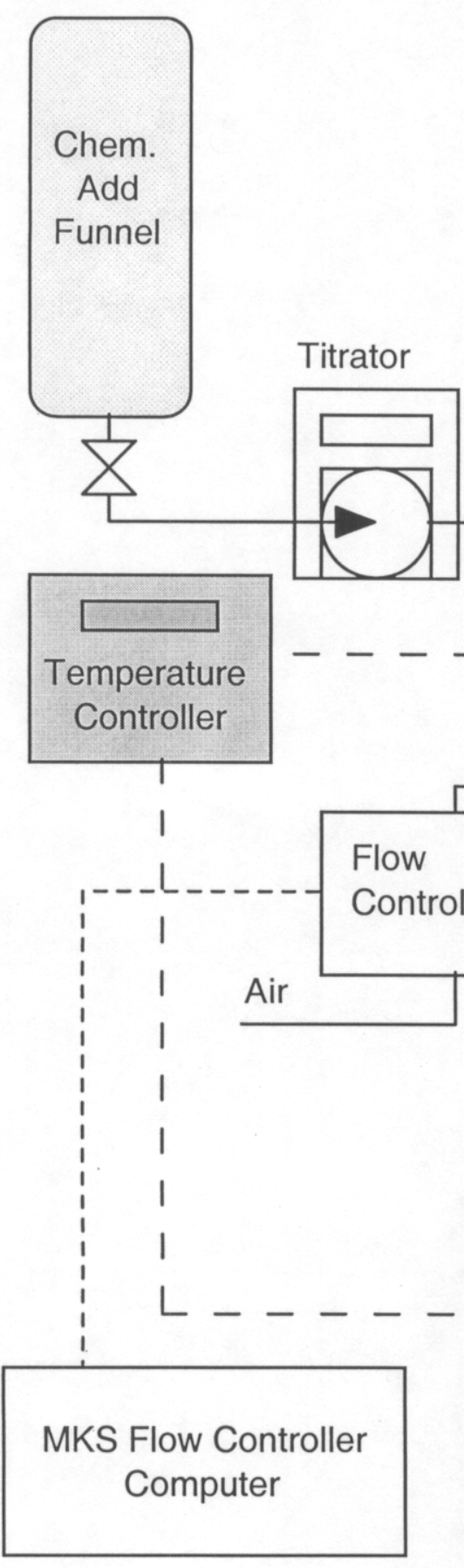

Appendix B-1

WSRC-TR-2001-00126

Page B1-2 of B1-3 
S. L. Marra

SRT-PTD-2000-0097

December 7, 2000

Page 3 of 3

Attachment Two: Calculation of Washing Requirements

\section{Given}

Supernate $\mathrm{Na}$ concentration of washed sludge

0.50

0.25

Sludge weight percent solids

15.4

Sludge density

1.11

Density of supernate

1.03

\section{Calculation}

Solids weight in $1 \mathrm{~L}$ of sludge $\quad 171$

Water weight in $1 \mathrm{~L}$ of sludge $\quad 939$

Water volume

939

Initial Decant

200

Moles of sodium in supernate

Moles of sodium in initial decant

Moles of sodium remaining after initial decant

470

100

Wash volume

370

Sodium concentration after 1 st wash addition

Second decant volume

Moles of sodium in second decant

Moles of sodium remaining after second decant

0.316

430

136

234

Final addition

200

Final supernate volume

939

Final sodium concentration in wash sludge

0.249

molar

molar

wt\%

$\mathrm{g} / \mathrm{ml}$

$\mathrm{g} / \mathrm{ml}$

grams

grams

$\mathrm{ml}$

$\mathrm{ml}$

millimoles

millimoles

millimoles

$\mathrm{ml}$

molar

$\mathrm{ml}$

millimoles

millimoles

$\mathrm{ml}$

$\mathrm{ml}$

molar

\section{Full Batch Calculations}

Batch Size

liters

Initial Decant

500

$\mathrm{ml}$

First wash volume

1075

1075

$\mathrm{ml}$

Second Decant volume

500

$\mathrm{ml}$

$\mathrm{ml}$ 


\section{WESTINGHOUSE SAVANNAH RIVER COMPANY INTEROFFICE MEMORANDUM}

December 7, 2000

To:

S. L. Marra, 704-1T

From: M. E.Stone, 704-1T MVC/K

\section{Run Plan for Preparation of Macrobatch 3 Underwashed Sludge (U)}

This document provides the necessary instructions for preparation of Macrobatch 3 underwashed sludge to be utilized during melt rate tests on Macrobatch 3 sludge simulant. Macrobatch 3 is assumed to be a $48 \%$ Tank 8 and 52\% Tank 40 blend (based on air-dried solids content). The four liter laboratory scale SRAT kettle will be configured as shown in Attachment One.

After addition to the kettle the sludge will be trimmed as shown in Table 1. The noble metal additions are based on the chemical process cell tests for this sludge, as documented in SRT-PTD-2000-48 and shown in Table 1. No mercury will be added due to offgas concerns when the material is vitrified. Addition of the manganese oxide and nickel chloride hexahydrate are based on the 3L baseline run, as documented in SRTPTD-2000-0071. Calculation of the addition amount for the soluble sodium species and rinse water amount is shown in Attachment Two.

Table 1. Trim Chemical Additions

\begin{tabular}{|l|c|}
\hline Chemical & $\begin{array}{c}\text { Addition Amount } \\
\text { (grams) }\end{array}$ \\
\hline Silver Nitrate & 0.8741 \\
\hline Palladium Nitrate Hydrate & 2.7800 \\
\hline Rhodium Nitrate Dihydrate & 1.3014 \\
\hline Ruthenium Chloride & 2.1394 \\
\hline Nickel Chloride Hexahydrate & 3.16 \\
\hline Manganese Oxide (85\%) & 6.047 \\
\hline Sodium Nitrate & 14.05 \\
\hline Sodium Nitrite & 20.19 \\
\hline Sodium Hydroxide & 10.18 \\
\hline Deionized Water & 236 \\
\hline
\end{tabular}

After trim chemical addition, the sludge will be mixed thoroughly and a $40 \mathrm{ml}$ sample pulled. Analysis of the sample must be expedited to allow the acid addition calculations to be performed.
c: $\quad$ L. F. Landon, 704-1T
D. P. Lambert, 704-1T
D. C. Koopman, 704-1T
D. C. Witt, 704-1T
D. K. Peeler, 773-43A
PTD Files
T. H. Loirer, 773-23A
Melt Rate Notebook


S. L. Marra

SRT-PTD-2000-0097

December 7, 2000

Page 2 of 3

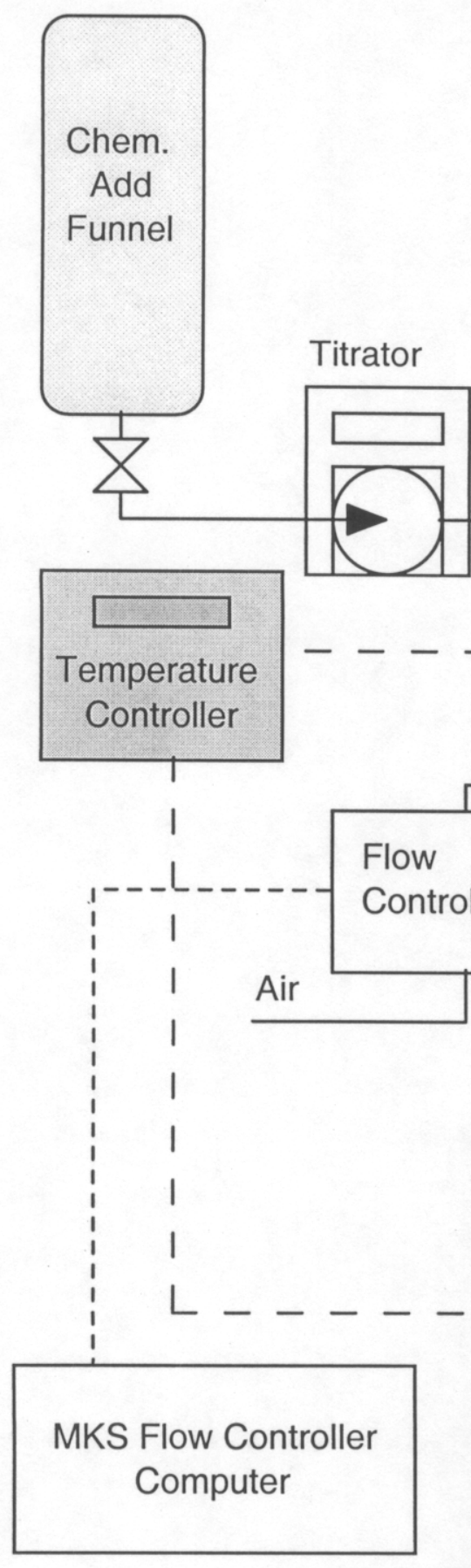

Appendix B-2

WSRC-TR-2001-00126

Page B2-2 of B2-3 
December 7, 2000

Page 3 of 3

\section{Attachment Two. Underwashed Sludge Sodium Trim (One less wash)}

\section{Given}

Supernate $\mathrm{Na}$ concentration of washed sludge

Supernate $\mathrm{Na}$ concentration of underwashed sludge

Sludge weight percent solids

Sludge density

Density of supernate

Concentration of hydroxide in sludge

Concentration of nitrate in sludge

Concentration of nitrite in sludge

Calculation of Soluble Sodium Addition per Liter

Solids weight in $1 \mathrm{~L}$ of sludge

Water weight in $1 \mathrm{~L}$ of sludge

Water volume in $1 \mathrm{~L}$ of sludge

Change in $\mathrm{Na}$ concentration

Moles of $\mathrm{Na}$ required per liter of sludge

Ratio of nitrite to nitrate

Ratio of hydroxide to nitrate

Moles of sodium nitrate required per liter of sludge

Moles of sodium hydroxide required per liter of sludge

Moles of sodium nitrite required per liter of sludge

Grams of sodium nitrate required per liter of sludge

Grams of sodium hydroxide required per liter of sludge

Grams of sodium nitrite required per liter of sludge

Total Solids after solids addition

Total weight after solids addition

Weight \% solids after solids addition

Supernate Addition per Liter

Moles of sodium nitrate in supernate addition

Grams of sodium nitrate in supernate addition

Grams of sodium nitrite in supernate addition

Grams of sodium hydroxide in supernate addition

Total Solids after supernate addition

Total weight after supernate addition

Weight \% solids after supernate addition

Total Additions per Liter

Water

Sodium Nitrate

Sodium Nitrite

Sodium Hydroxide

Full Batch Calculations

Batch Size

Grams of water required

Grams of sodium nitrate required

Grams of sodium hydroxide required

Grams of sodium nitrite required
0.50 molar

0.73 molar

$15.4 \quad w t \%$

$1.11 \mathrm{~g} / \mathrm{ml}$

$1.03 \mathrm{~g} / \mathrm{ml}$

0.2 molar

0.13 molar

0.23 molar

171 grams

939 grams

$939 \mathrm{ml}$

0.230 molar

0.216 moles

$1.77 \mathrm{~mol} / \mathrm{mol}$

$1.54 \mathrm{~mol} / \mathrm{mol}$

0.0501 moles

0.0771 moles

0.0887 moles

4.26 grams

3.09 grams

6.12 grams

184.4 grams

1123.5 grams

16.41 wt \%

$94.43 \mathrm{ml}$

0.02 moles

1.36 grams

1.95 grams

0.98 grams

188.7 grams

1222.2 grams

15.44 wt \%

$94.43 \mathrm{ml}$

5.62 grams

8.07 grams

4.07 grams

$\begin{array}{cc}2.5 & \text { liters } \\ 236.064 & \text { grams } \\ 14.05 & \text { grams } \\ 10.18 & \text { grams } \\ 20.19 & \text { grams }\end{array}$

